\title{
Research on Settlement and Deformation Control of Newly-built High-speed Railway and Existing Line Foundation under Different Overlap and Filling Types
}

\author{
Wen-yi Li ${ }^{1, a^{*}}$, Chao-qi Jin ${ }^{2,3}$, Jun-hua Zhu ${ }^{2,3}$, Hao-sen Guo ${ }^{2,3}$, Wen-jun Luo ${ }^{2}$, Li Chen ${ }^{2}$ \\ ${ }^{1}$ China Railway No.2Engineering Group CO., LTD, Chengdu, Sichuan, 610031, China \\ ${ }^{2}$ East China Jiaotong University, Nanchang, Jiangxi , 330013 , China \\ ${ }^{3}$ Engineering Research \&Development Centre for Underground Technology of Jiangxi Province, Nanchang, Jiangxi, 330013, China
}

\begin{abstract}
Subgrade filling of high-speed railway will cause additional settlement and deformation of existing lines.In this paper,using the finite element analysis platform (Taxis 2D) and considering the settlement of the existing line itself, This paper analyzes the impact of the new and old subgrade lap type and the layer filled this lesson of the new subgrade on the implementation of the existing subgrade. The results illustrate the following points:(1) Compared with different overlapping surface types, different filling those points have a greater impact on the settlement of the existing line; (2) The height of the steps is $0.6 \mathrm{~m}$ and the width is $1.0 \mathrm{~m}$.In the subsequent layered filling construction process, each level The loading capacity of $30 \mathrm{~cm}$ is more reasonable, which can effectively control the influence of the existing line on the additional settlement of the existing railway. The research results can provide a reference for the optimization of similar roadbed width construction.
\end{abstract}

\section{Introduction}

With the continuous development of China's economy and transportation, high-speed railway has achieved rapid development. With the continuous development and improvement of high-speed railway network, it is inevitable that the new railway will be paralleled, crossed or widened with the existing lines which have been put into operation. At present, there are more and more similar engineering practices.For the reconstruction of the existing railway subgrade, due to the high requirements for deformation of the railway, compared with the highway, there are more stringent requirements for the settlement of the existing line after construction. And the construction near the high-speed railway will inevitably disturb the subgrade section of the existing high-speed railway, resulting in various types of deformation, causing track irregularity, and then affecting the comfort and safety of train operation It brings great risk to train operation. Therefore, settlement control is undoubtedly an important part of railway design and construction. It is of great significance to adopt reasonable and reliable analysis methods to solve this problem.

At present, there is no unified and specific design specification and standard for the subgrade reconstruction and expansion of high-speed railway in China, and there are few studies on the impact of subgrade filling on adjacent business lines and related cases in foreign literature. The current research on railway subgrade widening, Glenn Caverson and so on ${ }^{[1]}$ aiming at the "GO Transit" railway line subgrade expansion project in Toronto West, Canada, the silo gravity retaining wall and geosynthetics reinforced soil are used to reinforce the new roadbed slope. The practical effect shows that the reinforcement effect is good. Liu Junfei ${ }^{[2]}$ studied the influence of soil piling outside the existing railway on the subgrade settlement, and through the analysis of the distribution characteristics of additional stress in CFG pile composite foundation and the additional stress distribution characteristics generated by the additional load on the outside of the subgrade, the influence mechanism and settlement deformation estimation method of the lateral pile soil on the subgrade settlement are proposed. Wang Xingrong ${ }^{[3]}$ studied the construction design of ballastless track subgrade widening project of a passenger dedicated line, and the results show that the settlement control effect of non soil pile such as pipe pile is remarkable for foundation reinforcement of widened subgrade engineering, and have an different construction sequence and filling rate also have influence on settlement control. Yang Quan et $\mathrm{al}^{[4]}$ studied the construction scheme of the new line adjacent to the existing Ballastless high-speed railway subgrade, and the research shows that when the natural foundation is reinforced by micro piles and the embankment filling material is replaced by light concrete, the impact of the new line construction on the existing high-speed railway reaches the minimum. Hu Runqian ${ }^{[5]}$ used the finite element software MIDAS GTS NX to simulate the reinforcement effect of jet grouting pile and 
steel pipe micro pile under the condition of subgrade filling with ordinary filler and light concrete. The calculation results show that the treatment method of "steel pipe micro pile + light concrete" can better control the settlement of Existing Subgrade during and after the construction of subgrade widening.

In addition, the finite element method software ${ }^{[6 \sim 10]}$ is often used to calculate the additional settlement. Compared with the traditional layered summation method, the finite element method can consider the interaction between the new and the old subgrade. However, at present, the selection of soil constitutive model for finite element numerical simulation and the field simulation of construction site are too simple, Moreover, it is easy to ignore the consolidation settlement of the foundation under the long-term operation of the existing line, and there is no control standard for the short-term settlement displacement of the construction.

In view of the above problems, this paper takes Nanchang Changjing Huanghe railway subgrade construction as an example, considering the standard of settlement displacement control, with the finite element analysis platform $\left(\mathrm{PLAXI}^{2 \mathrm{D}}\right)$, a two-dimensional numerical analysis model is established to explore the influence mechanism of different lap type and layer thickness on adjacent business lines in high-speed railway subgrade filling construction. Combined with the requirements of allowable deviation management value of track static geometric dimension, the short-term settlement value of special construction scheme of construction unit is used to control the additional settlement deformation of existing railway.

\section{Overview of the project}

The newly built Changjinghuang Railway is Nanchang via Jingdezhen to Huangshan High Speed Railway, with a design speed of $350 \mathrm{~km} / \mathrm{h}$, CJHZQJX-7 marked as the tie line project connecting the newly built Nanchang East Station and the existing Nanchang West Station. Design speed $200 \mathrm{~km} / \mathrm{h}$; tie line from Nanchang East Station from Henggang tie line to Beijing-Kowloon upper and lower line parallel access Henggang station, and then from Xiangzhi tie line left and right line to Henggang station.

The Henggang Left Line is adjacent to the BeijingKowloon Downlink K1460+725 K1462+725 and $\mathrm{K} 1464+800 \sim \mathrm{K} 1465+635$, with a line spacing of $5 \sim 40 \mathrm{~m}$; the Henggang Right Line is adjacent to the BeijingKowloon Uplink K1460+725 K1462+725 and K1464+ $800 \sim \mathrm{K} 1465+605$, the line spacing is $5 \sim 21 \mathrm{~m}$; the design speed of this section of Beijing-Kowloon Line is $120 \mathrm{Km} / \mathrm{h}$.

The topography and geomorphology of the adjacent business line: the height difference of the adjacent business line is not large, and the surface layer is mostly mixed fill and silty clay, which is excavated and filled. The average excavation height is $2.4 \mathrm{~m}$, the local maximum excavation height is $7 \mathrm{~m}$; the average filling height is 2.4 $\mathrm{m}$, the maximum filling height is $6.8 \mathrm{~m}$.

The geological conditions in this area are complex and belong to Poyang Lake Plain and terrace area. There are typical binary geological structures, silt soil and loose sand in the upper part, and rich water coarse sand layer in the lower part (coarse sand and round gravel soil). The layer thickness of the overlying silty clay is about $8 \mathrm{~m}$ and the layer thickness of fine sand soil is about $9 \mathrm{~m}$. Surface water is mainly ditch water, river, groundwater is mainly loose rock pore water, bedrock fissure water. The groundwater level is generally $0.5 \sim 2 \mathrm{~m}$, with weak pressure. The mileage of skylight operation is long, and the railway structure is not only affected by the construction of infrastructure under adjacent rail, but also by train dynamic load. The physical and mechanical parameters of the foundation soil are shown in Table 1.

Table 1.Summary of detailed parameters of soil layer

\begin{tabular}{lccccc}
\hline Project & $\begin{array}{l}\text { Layer } \\
\text { thickness } \\
/(\mathrm{m})\end{array}$ & $\begin{array}{l}\text { Severe } \\
\text { degree } \\
/\left(\mathrm{kN} / \mathrm{m}^{3}\right)\end{array}$ & $\begin{array}{l}\text { Cohesion } \\
/(\mathrm{kPa})\end{array}$ & $\begin{array}{l}\text { Angle of } \\
\text { friction } \\
/\left({ }^{\circ}\right)\end{array}$ & $\begin{array}{l}\text { Poisson's } \\
\text { ratio }\end{array}$ \\
\hline $\begin{array}{l}\text { Silty } \\
\text { clay }\end{array}$ & 8 & 16 & 20 & 18 & 0.2 \\
$\begin{array}{l}\text { Fine } \\
\text { sand }\end{array}$ & 9 & 20 & 6 & 28 & 0.2 \\
\hline
\end{tabular}

Considering the standard of controlling settlement displacement and combining with the requirement of allowable deviation management value of track static geometric dimension, Table 2 is taken as the settlement control standard of existing business line in the actual monitoring process.

Table 2.Standard Tables for Base Settlement Control of Business Lines

\begin{tabular}{|c|c|c|c|}
\hline & Single & Cumulative & $\begin{array}{c}\text { Difference } \\
\text { settlement } \\
\text { of adjacent } \\
\text { points }\end{array}$ \\
\hline $\begin{array}{c}\text { Subgrade } \\
\text { settlement }\end{array}$ & $\leq 2 \mathrm{~mm}$ & $\leq 10 \mathrm{~mm}$ & $\leq 5 \mathrm{~mm}$ \\
\hline $\begin{array}{c}\text { Slope } \\
\text { displacement }\end{array}$ & $\leq 0.5 \mathrm{H} \% 0$ & $\leq 2 \mathrm{H} \%$ & $/$ \\
\hline
\end{tabular}

\section{Model Establishment}

A finite element analysis platform (Plaxis 2D) is used to establish a numerical analysis model for sensitivity analysis. During the selection of model size, the width of subgrade filling is fully considered, the depth of cutting excavation is the influence range with the existing line, and the model size is $60 \mathrm{~m} \times 20 \mathrm{~m}$, As shown in fig. 1,1086 units and 9021 nodes have been generated.

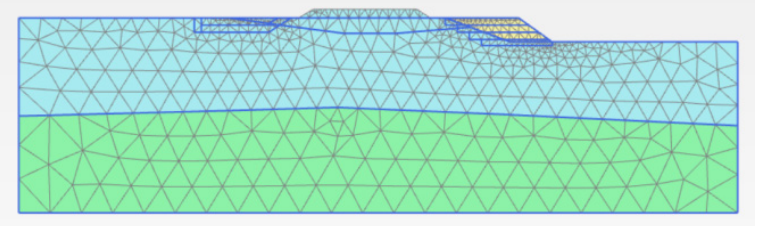

Figure 1. Finite element model of typical subgrade filling section

In the model, the small strain stiffness model is used in the foundation soil, and the molar Coulomb model is used 
in the subgrade. A typical $2 \mathrm{D}$ geological model of subgrade filling section is established, and the sensitivity analysis of the two influencing factors in Table 3 is carried out to determine the sensitivity of the following factors to the settlement of existing subgrade in the process of subgrade filling. The concrete numerical simulation construction steps are as follows: step 1, initial stress balance; step 2, long-term settlement of existing railway line, activation load; step 3, soil excavation, freezing soil on both sides; step 4; new line foundation stratified filling, Activate soil on both sides and calculate the influence of different construction methods on existing railway line. The subgrade parameters are detailed in Table 4.

Table 3. Sensitivity analysis of influencing factors of wide section of roadbed

\begin{tabular}{|c|c|c|c|}
\hline $\begin{array}{l}\text { Influencing } \\
\text { factors }\end{array}$ & Level of factors & $\begin{array}{l}\text { Influencing } \\
\text { factors }\end{array}$ & Level of factors \\
\hline \multirow{5}{*}{$\begin{array}{l}\text { New and Old } \\
\text { Subgrade } \\
\text { Laptop Type }\end{array}$} & $\begin{array}{l}\text { Height: } 0.6 \mathrm{~m} \\
\text { Width: } 1.0 \mathrm{~m}\end{array}$ & \multirow{5}{*}{$\begin{array}{l}\text { Stratified } \\
\text { thickness }\end{array}$} & $10 \mathrm{~cm}$ \\
\hline & Height:0.6m & & $20 \mathrm{~cm}$ \\
\hline & Width: $1.2 \mathrm{~m}$ & & \\
\hline & Height: $0.8 \mathrm{~m}$ & & $30 \mathrm{~cm}$ \\
\hline & $\begin{array}{l}\text { Height: } 0.8 \mathrm{~m} \\
\text { Width: } 1.6 \mathrm{~m}\end{array}$ & & $40 \mathrm{~cm}$ \\
\hline
\end{tabular}

Table 4.Summary of Base Parameters for Existing and New

\begin{tabular}{|c|c|c|c|c|c|}
\hline \multicolumn{6}{|c|}{ Lines } \\
\hline Project & $\begin{array}{l}\text { Severe } \\
\text { degree } \\
/\left(\mathrm{kN} / \mathrm{m}^{3}\right)\end{array}$ & $\begin{array}{l}\text { Elastic } \\
\text { modulus } \\
/(\mathrm{MPa})\end{array}$ & $\begin{array}{l}\text { Poisson's } \\
\text { ratio }\end{array}$ & $\begin{array}{l}\text { Cohesion } \\
/ \mathrm{kPa}\end{array}$ & $\begin{array}{l}\text { Angle } \\
\text { of } \\
\text { friction } \\
/\left(^{\circ}\right)\end{array}$ \\
\hline $\begin{array}{l}\text { Existing } \\
\text { Subgrade }\end{array}$ & 19 & 98 & 0.3 & 21.8 & 22 \\
\hline $\begin{array}{l}\text { Base bed } \\
\text { surface }\end{array}$ & 24 & 158 & 0.24 & 22 & 32 \\
\hline Base bed & 19 & 116 & 0.3 & 21.5 & 22 \\
\hline Ballast & 20 & 400 & 0.15 & 0 & 25 \\
\hline
\end{tabular}

In order to consider the long-term settlement of the existing subgrade itself under the train load, the model first applies the dynamic stress load of the ballasted track train on the existing roadbed, calculates the plasticity and resets the displacement to zero, then carries on the sensitivity analysis. Current train speed $160 \mathrm{~km} / \mathrm{h}$, dynamic stress formula according to railway subgrade design ${ }^{[11]}$ :

$$
\begin{aligned}
& \quad \sigma_{d}=0.26 \times P \times(1+0.004 V) \\
& \sigma_{\mathrm{d}}-\text {-Design dynamic stress of subgrade surface }(\mathrm{k} P \mathrm{a}) \\
& P-\text { - Static axis gravity }(\mathrm{KN}) ; \\
& V-\text { - Train speed per hour }(\mathrm{km} / \mathrm{h})
\end{aligned}
$$

\section{Settlement deformation analysis}

In the process of subgrade filling, the load of the new subgrade increases continuously, and the closer the subgrade is, the greater the settlement value is. After the completion of the construction of the existing line foundation, in addition to the additional settlement of the existing subgrade during the construction, the new and old subgrade will continue to settle gradually during the period of reserved settlement after construction and in the course of operation until the two reach a balanced state. By numerical simulation of different new and old subgrade lap surface types, the vertical displacement cloud map (Fig .2) and the final deformation grid map (Fig .3). The maximum settlement of the whole model occurs near the center of the base surface of the new line, that is, near the ballastless track, which is caused by the combined action of the new fill and the load. Because the right side is subgrade filling and the left side is backfill after cutting excavation, the settlement displacement of the new line on the right side is obvious, and the existing line is slightly inclined to the right after the load of the new fill on the right side.

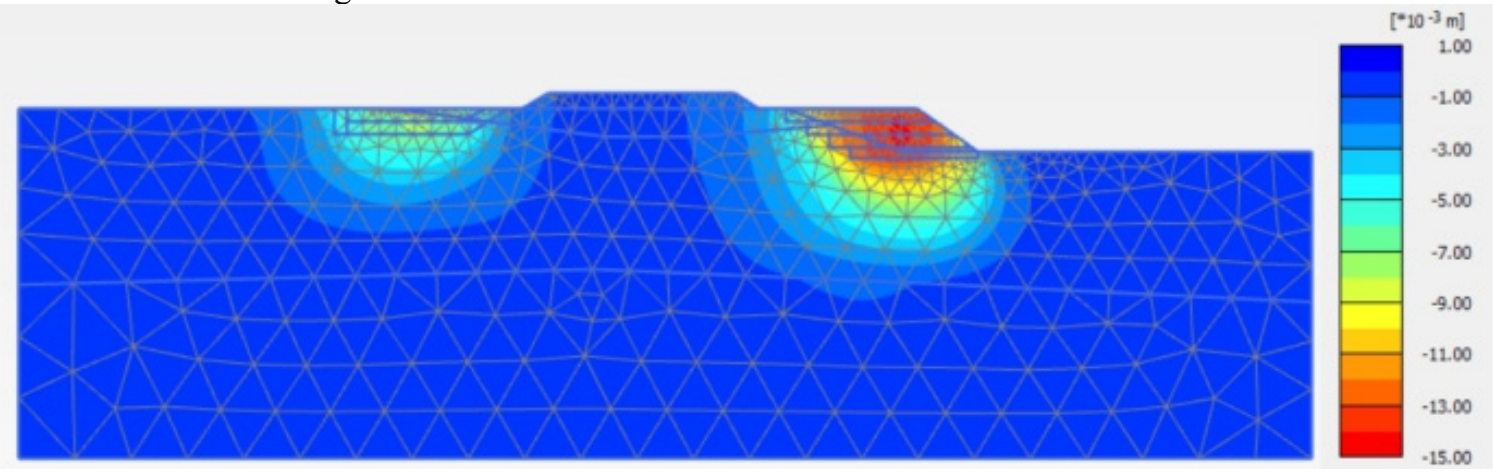

Figure 2. Vertical settlement cloud map of lap surface (type of lap surface)

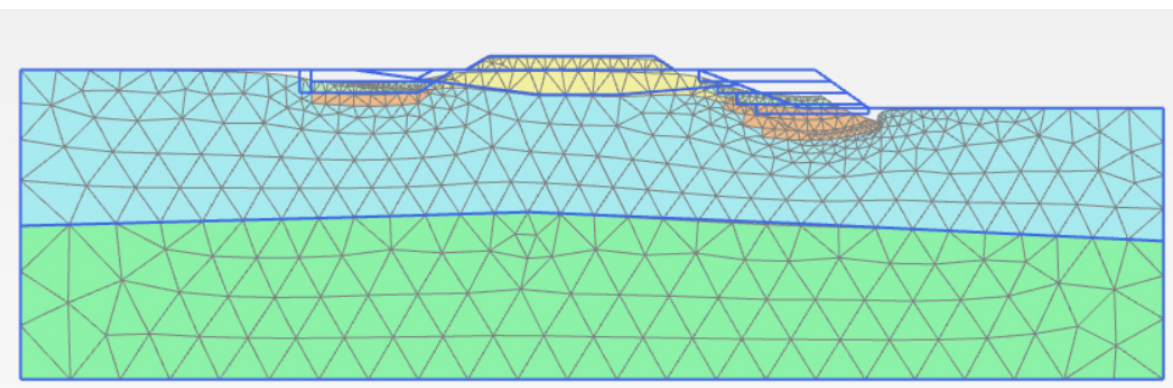

Figure 3.Final deformed mesh (100 times magnification) 
We selected four observation points, as shown in Figure 4, which are located on the right existing line, the left existing line, the right side slope and the left side slope.The concrete numerical analysis is carried out, and the analysis results are shown in Table 5. The results show that the increase of step width can reduce the vertical displacement settlement of the existing line, but has little effect on the vertical displacement settlement of the slope. On the contrary, when the step width is constant, the step height increases and the slope vertical displacement decreases. Considering the criterion of controlling the short-term settlement displacement, the influence factors of the change of the lap surface type on the existing line displacement control are relatively small. The results of numerical simulation show that the vertical settlement

displacement of the existing line can meet the short-term settlement control standard of construction, but it is difficult to reach the short-term settlement control standard by changing the type of lap surface in the slope.

Table 5. Comparative analysis of existing line sediment values

\begin{tabular}{ccccc}
\hline \multirow{2}{*}{$\begin{array}{l}\text { New and Old } \\
\text { Subgrade Laptop } \\
\text { Type }\end{array}$} & \multicolumn{3}{l}{$\begin{array}{l}\text { Maximum settlement of } \\
\text { existing lines/(mm) }\end{array}$} & \multicolumn{2}{l}{$\begin{array}{l}\text { Vertical } \\
\text { existing }\end{array}$} & $\begin{array}{c}\text { settlement } \\
\text { slope } /(\mathrm{mm})\end{array}$ \\
\cline { 2 - 5 } & Left & Right line & Left & Right \\
\hline $\begin{array}{l}\text { Height:0.6m } \\
\text { Width: } 1.0 \mathrm{~m}\end{array}$ & -0.796 & -1.273 & -4.964 & -5.797 \\
$\begin{array}{l}\text { Height:0.6 m } \\
\text { Width: } 1.2 \mathrm{~m}\end{array}$ & -0.792 & -1.203 & -4.590 & -5.781 \\
$\begin{array}{l}\text { Height:0.8m } \\
\text { Width: } 1.2 \mathrm{~m}\end{array}$ & -0.837 & -1.406 & -2.150 & -5.050 \\
$\begin{array}{l}\text { Height:0.8m } \\
\text { Width: } 1.6 \mathrm{~m}\end{array}$ & -0.803 & -1.190 & -2.119 & -4.926 \\
\hline
\end{tabular}

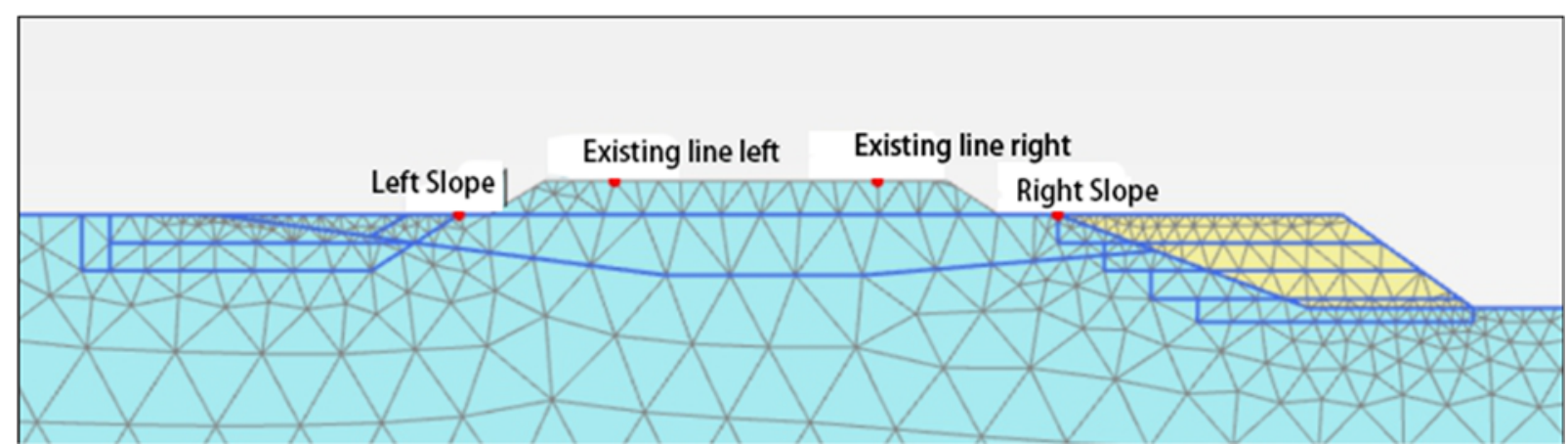

Figure 4.positioning of observation points

Combined with the results of the previous sensitivity numerical simulation analysis, under the condition of satisfying the construction requirements, considering the control of construction cost, reducing the excavation of earthwork and controlling economic indexes, At the same time, reducing the amount of soil excavated from the old embankment can effectively reduce the risk of instability of the old embankment ${ }^{[8]}$ so as to improve the stability of the old subgrade. Therefore, under the condition of the first lap type "high $0.6 \mathrm{~m}$ wide $1.0 \mathrm{~m}$ ", we analyzed the sensitivity of delamination thickness.According to the principle that layer thickness is a multiple of the step height ,we took different thickness of $10 \mathrm{~cm}, 20 \mathrm{~cm}, 30 \mathrm{~cm}$ and $60 \mathrm{~cm}$, and we analyzed Sensitivity of existing lines. The vertical displacement cloud map (Fig .5) and observation point settlement value (Table 6).

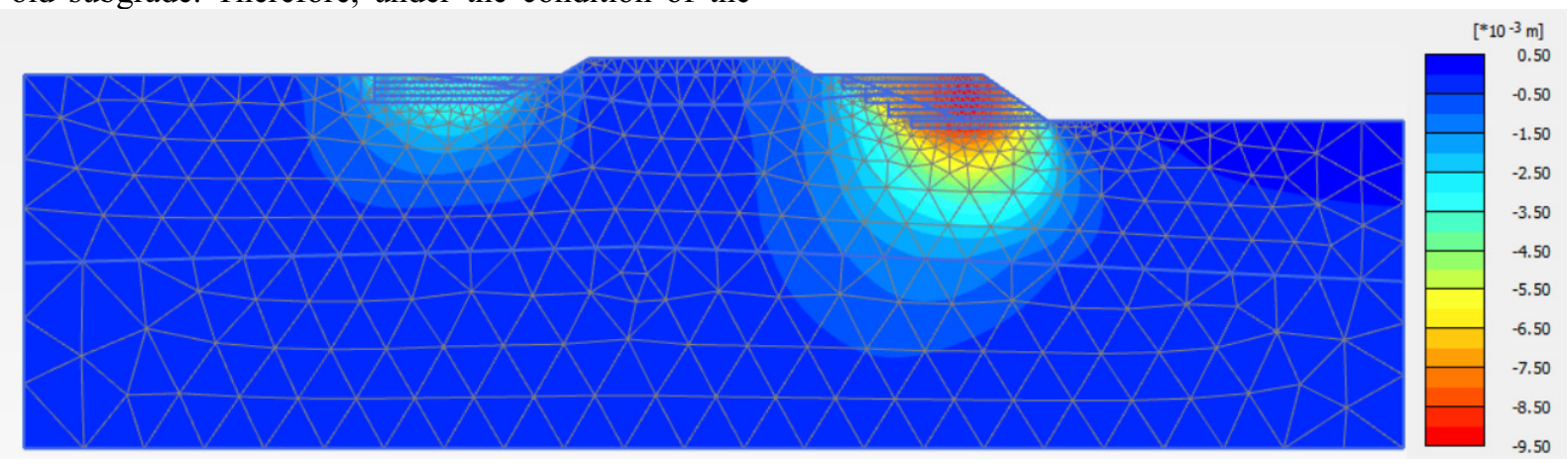

Figure 5.Vertical displacement clouds (layer thickness) 
Table 6.Comparative analysis of existing line sediment values

\begin{tabular}{ccccc}
\hline \multirow{2}{*}{$\begin{array}{c}\text { Stratified } \\
\text { thickness }\end{array}$} & \multicolumn{2}{c}{$\begin{array}{c}\text { Maximum settlement of } \\
\text { existing lines/(mm) }\end{array}$} & \multicolumn{2}{c}{$\begin{array}{c}\text { Vertical settlement of } \\
\text { existing slope } /(\mathrm{mm})\end{array}$} \\
\cline { 2 - 5 } & Left & Right line & Left & Right \\
\hline $10 \mathrm{~cm}$ & -0.076 & -0.280 & -0.390 & -1.635 \\
$20 \mathrm{~cm}$ & -0.277 & -0.489 & -0.828 & -2.216 \\
$30 \mathrm{~cm}$ & -0.346 & -0.655 & -0.951 & -2.801 \\
$60 \mathrm{~cm}$ & -0.802 & -1.498 & -2.053 & -5.811 \\
\hline
\end{tabular}

It can be seen from Table 6 that the selection of different delamination thickness will have a great impact on the existing line. With the decrease of the delamination thickness, the vertical settlement displacement at the existing line and slope will gradually decrease, and with the doubling of the thickness, The settlement position of the existing line will change exponentially. The calculation results show that the displacement values of existing lines and slopes meet the construction short-term settlement standard control only when the delamination thickness is $10 \mathrm{~cm}, 20 \mathrm{~cm}, 30 \mathrm{~cm}$. Considering that the selection of delamination thickness will determine the time arrangement of spreading and rolling, the thicker the filling thickness and the shorter the subgrade filling period. Compared with the selection of new and old lap surfaces, the existing lines are more sensitive to the delamination thickness. In the actual construction scheme, the selection of stratified thickness should be fully considered in combination with the actual construction situation and standard control, which has achieved the purpose of reducing the influence on the adjacent business line during the construction of railway subgrade filling.

In addition, the high-speed railway requires high settlement, and the interference to the existing line should be reduced as far as possible during the construction process. It is suggested that the operation of large machinery should be prohibited by the existing line in construction, and the deformation monitoring measures of the existing subgrade and track should be taken.

To sum up, the scheme of "0.6 m $1.0 \mathrm{~m}$ "and "30 layers thickness" is recommended for the typical roadbed width of the newly built Changjinghuang Railway to improve the effective utilization of resources and shorten the construction period. It is beneficial to the control of construction schedule and cost. The speed limit treatment and real-time monitoring measures are carried out on the high-speed railway. The simulated condition, the parameter value and the calculation result may be different from the actual situation, which needs to be verified by the actual engineering.

\section{Conclusion}

The finite element analysis platform (Plaxis 2D) is used to establish the numerical analysis model. Based on the engineering examples of the subgrade filling section (HGLYDK11+420.22 HGLZDK 13+535.017) of Henggang Station in the project, the numerical simulation results of various influencing factors are compared and analyzed. The following conclusions are drawn:

(1) After the embankment is wide, due to the large filling height of the right line, the additional settlement value produced by the right line of the existing roadbed is larger than that produced by the left side, that is, the greater the height of the embankment, the greater the influence on the settlement of the existing railway line.

(2) After the embankment is widened, the existing subgrade produces longitudinal additional settlement deformation. After the new subgrade is layered and filled, the additional settlement of the existing subgrade is reduced. In the process of widening and expanding the existing line, the excavating amount of the old embankment is reduced, and the loading amount of each grade in the new embankment is reduced. Can effectively reduce the impact of new line construction on adjacent business lines.

(3) According to the sensitivity of each factor obtained from the simulation, the most sensitive factors are selected, and the simulation conditions are designed. The reasonable step excavation and layered filling scheme is as follows: first, the humus soil of the upper layer of the old side slope is removed and then the steps are excavated on the old side slope. The loading capacity of each stage is $30 \mathrm{~cm} \mathrm{~m}$, the width of 0.6 step is 1.0 .

(4) Comparing the two different sensitivities, it can be seen from the analysis of the calculated value of the additional settlement produced by the existing line that the existing line is more sensitive to the thickness of each layer in the process of layered filling than the selection of the new and old lap surface.

\section{Acknowledgments:}

This work is supported by project(20202BABL214051) of Jiangxi Natural Science Foundation, science and technology projects (2018H0042 and 2016H0025) of Jiangxi Provincial Department of transportation.

\section{References}

1. Caverson I G,Lowry D.Case Study-Railway Embankment Widening for $\mathrm{CN}$ Rail and GO Transit[M]. 2011.

2. Liu Junfei. Estimation of the Influence of Outer Pile of Existing Railway on Subgrade Settlement [J]. Railways Standard ,2014,58(S1)126-128

3. Wang Xingrong. Design and Practice of Subgrade Widening Engineering for Passenger Dedicated Line [J].]; and Railway Standard Design ,2014(1):38-41.

4. Yang Quan, Gao Baisong, Li Jingyuan, Xiao Feizhi, $\mathrm{Xu}$ Jun. A Study on Subgrade Construction of New Line Near Existing Ballast High Speed Railway [J].] High Speed Railway Technology 7(02):15-19.

5. Yang Quan, Gao Baisong, Li Jingyuan, Study on the Construction Scheme of et al. New Line near existing Ballastless High Speed Railway Subgrade High Speed Railway Technology, v.7;No.37(02) : 1923.,2016

6. Hu Runqian. A Study on the Settlement Control of the Broad Section of Subgrade of a High Speed Railway [J].] Railway Standard Design 2017(05):6164.2014/58(S1):126-128.

7. Sun Mingchao. A Study on the Control Technology of 
Subgrade Settlement Deformation of High Speed Railway Subgrade Railway Survey ,2019,45(04):4649.

8. Liu Yuanhao, Hu Zhongchun, Ren Gao, Zhang Congrui, Jiao Jinqiang. Deformation Analysis and Scheme Optimization for Wide Construction of Existing Line Foundation [J]. Journal of Wuhan University of Engineering 40(02):190-196.

9. Zhang Wantao. Discussion on the Application of Deformation Control and Monitoring Technology for Subgrade Subgrade Filling in High-speed Railway [J].]; and Railway Standard Design 61(04):47-50.

10. Cai Wu. A Study on the Technical Practice of Base Wide Construction and Safety Protection of Adjacent Business Lines [J].] and Value engineering ,2016,35(17):127-130.

11. Zhou Shengen. Dynamic Load Study of Railway Subgrade Design [J].] Subgrade Engineering ,1996(05):6-11. 